\title{
Fishing behaviour by Black Caracaras (Daptrius ater) in the Amazon
}

\author{
Fabio Olmos $^{1}$ \& Ivan Sazima ${ }^{2,3,4}$ \\ ${ }^{1}$ Biota Consultores em Meio Ambiente, Largo do Paissandu 100, apt. 4C, \\ CEP 01034-010, São Paulo, SP, Brazil, e-mail:f-olmos@uol.com.br \\ ${ }^{2}$ Museu de Zoologia, Universidade Estadual de Campinas - UNICAMP, CP 6109, \\ CEP 13083-970, Campinas, SP, Brazil, www.unicamp.br \\ ${ }^{3}$ Corresponding author: Ivan Sazima, e-mail: isazima@gmail.com \\ ${ }^{4}$ Retired and associated as voluntary researcher
}

OLMOS, F. \& SAZIMA, I. Fishing behaviour by Black Caracaras (Daptrius ater) in the Amazon. Biota Neotrop. 9(3): http://www.biotaneotropica.org.br/v9n3/en/abstract?inventory+bn02309032009.

\begin{abstract}
The Black Caracara is a widespread raptor in the Amazonian lowlands, mostly associated to riverine habitats. This bird is considered as a generalist scavenger that occasionally takes small prey and feeds on fruit. Here we report on Black Caracaras foraging on live small fish caught while moving upriver in the Rio Roosevelt rapids in the Amazonas state, northwestern Brazil. Fish were picked individually either with the bill or talons in a stretch of shallow water plenty of aquatic plants. This fishing behaviour seems unreported and adds another feeding mode to the already diversified portfolio of foraging strategies for the Caracarini.

Keywords: raptorial birds, Black Caracara, Daptrius ater, fishing behaviour, Characidae.
\end{abstract}

OLMOS, F. \& SAZIMA, I. Comportamento de pesca pelo Gavião-de-anta (Daptrius ater) na Amazônia. Biota Neotrop. 9(3): http://www.biotaneotropica.org.br/v9n3/pt/abstract?inventory+bn02309032009.

Resumo: O Gavião-de-anta é uma ave de rapina amplamente distribuída nas terras baixas da Bacia Amazônica, geralmente associado a habitats ribeirinhos. Esta ave é considerada como um necrófago generalista que ocasionalmente captura pequenos animais e também se alimenta de frutos. Descrevemos aqui Gaviões-de-anta capturando pequenos peixes vivos que se deslocavam rio acima nas corredeiras do Rio Roosevelt, Amazonas. Os peixes eram apanhados individualmente, tanto com o bico como com as garras, em um trecho de águas rasas com muitas plantas aquáticas. Este comportamento parece não estar registrado e adiciona mais um modo alimentar ao repertório amplamente diversificado dos comportamentos de forrageio de Caracarini.

Palavras-chave: aves de rapina, Gavião-de-anta, Daptrius ater, comportamento de pesca, Characidae. 


\section{Introduction}

The Caracarini are a versatile group of Neotropical raptors known to exploit a wide range of animals dead or alive (see Sazima 2007 and references therein) and sometimes to feed on fruits (Guimarães \& Galetti 2004, Olmos et al. 2006). The Black Caracara Daptrius ater (Vieillot) is widely distributed over the lowlands of the Amazon Basin and the Guianas, found in pairs or small family groups of 3-5 birds (Peres 1996). It is commonest in forest along rivers and lakes (Robinson 1994) and also ventures along roads and cleared areas away from water (Ferguson-Lees \& Christie 2001, FO pers. obs.). Its diet is very diversified and includes palm fruits (Guimarães \& Galetti 2004), turtle eggs dug from riverbanks (Batistella \& Vogt 2008), ectoparasites removed from tapirs (Peres 1996), scavenged small mammals, reptiles and fish found as roadkills or discarded by humans (Ferguson-Lees \& Christie 2001, FO and IS pers. obs.) besides live small vertebrates and large arthropods (Ferguson-Lees \& Christie 2001).

We report here on Black Caracaras fishing live small fishes migrating en masse upstream, which may prove an usual (albeit unreported so far) foraging strategy for this species. We also note that this hunting mode adds a novelty to the already much diversified foraging repertoire of the Caracarini.

\section{Material and Methods}

Observations and records were made at the Pousada Rio Roosevelt, Amazonas state, northwestern Brazil. This fishing and ecotourism lodge lies in an undisturbed area of terra firme and seasonally flooded forests with scattered campinas covering about 1 million ha. Fishing Black Caracaras were recorded on 16 April 2008 from a small boat with outboard engine while searching for birds in the Rio Roosevelt rapids $\left(08^{\circ} 28^{\prime} 25^{\prime \prime} \mathrm{S}\right.$ and $\left.60^{\circ} 58^{\prime} 33^{\prime \prime} \mathrm{W}\right)$ downstream the Cachoeira de Santa Rita, which marks a long stretch of rapids with exposed boulders that must be negotiated by migratory fish moving upstream. "Ad libitum" and "behaviour" sampling rules (Martin \& Bateson 1986) were used throughout the observations made with naked eye, through binoculars, and a 170-400 $\mathrm{mm}$ photographic autofocus camera lens at a distance of 100-400 m. Observations were carried between 03:50-04:20 hours (local time). A series of digital photographs was taken as vouchers, besides being used for analyses, description and illustration of the feeding behaviours, a few of the most representative presented here.

\section{Results}

During the time of our visit the waters of the Rio Roosevelt were receding several centimetres every day (at least one meter during the previous three days), exposing large boulders almost completely covered with dense clumps of Podostemaceae. These aquatic, rapidsdwelling plants attracted large feeding flocks of Madeira Parakeets Pyrrhura snethlageae Joseph \& Bates, Golden-winged Parakeets Brotogeris chrysoptera (L.), and Blue-headed Parrots Pionus menstruus (L.). While observing these we noticed several Black Caracaras walking on the boulders by the river's east bank, some amidst the now exposed aquatic vegetation. A Great Black-hawk Buteogallus urubitinga (Gmelin) was perched on a higher boulder, apparently watching the activities of the caracaras. As we approached the hawk flew to a nearby tree, keeping its distance. The caracaras looked quite unconcerned by our presence, some even moving closer to the boat.

Five Caracaras were walking over the boulders or flying around. Three birds were positioned near a narrow cleft covered with aquatic vegetation between a massive boulder at the margin and a smaller
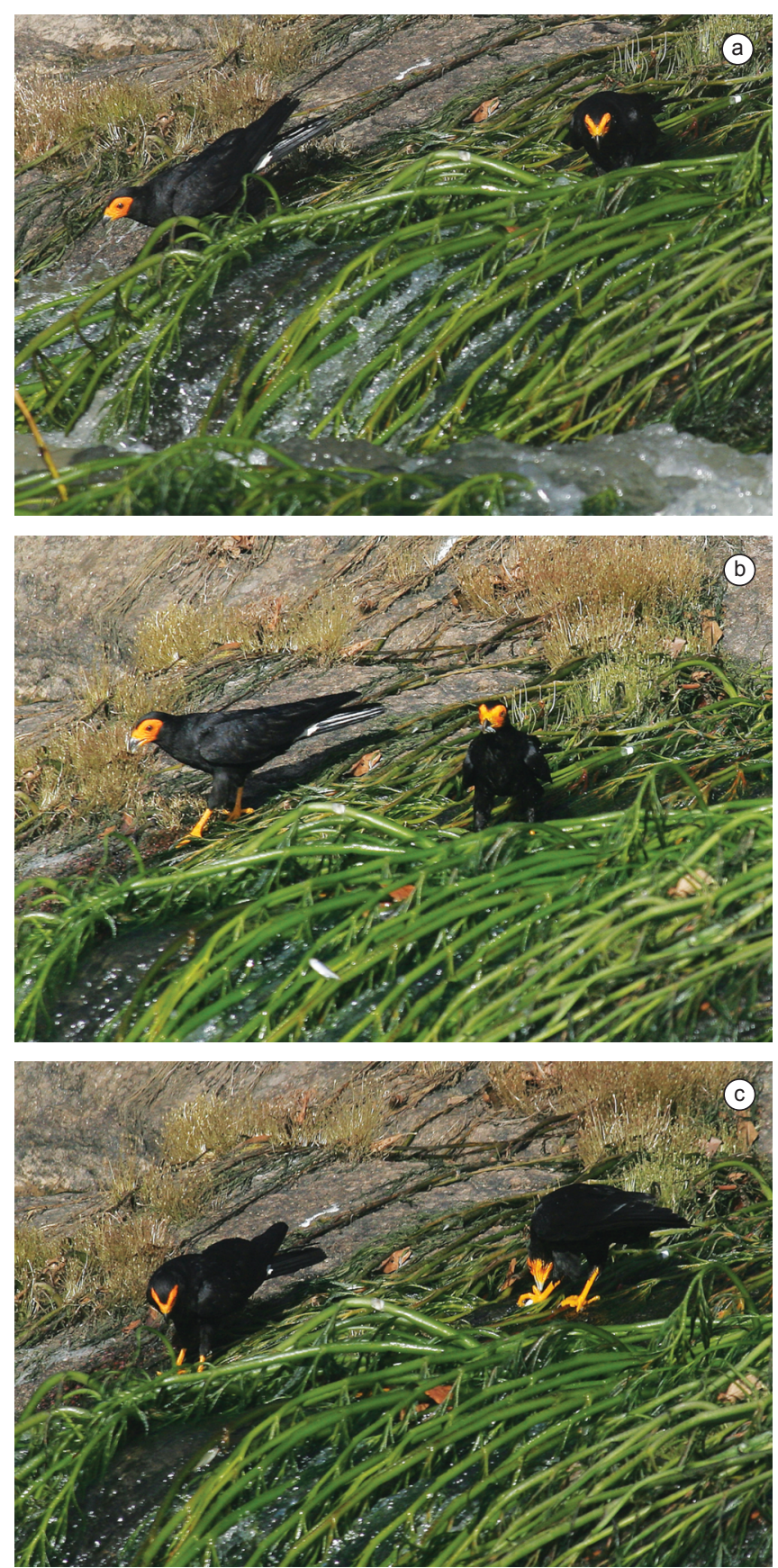

Figure 1. Fishing sequence by a Black Caracara (Daptrius ater) at the Rio Roosevelt, Amazon, northwestern Brazil. a) The birds search for small fish moving upstream among the Podostemaceae growing on the now shallow water running over the boulders at the river rapids; b) a fish (apparently a tetra, Characidae) is picked with the bill by the bird at the right; a fish jumping out the water is seen in the foreground near the centre of the picture; and c) the bird moves to a higher spot to feed on the fish held among the talons. The bird on the left on Figure $1 \mathrm{~b}$ also holds a fish in its bill.

Figura 1. Seqüência de pesca por um Gavião-de-anta (Daptrius ater) no Rio Roosevelt, Amazonas. a) As aves procuram por pequenos peixes que se deslocam correnteza acima em meio a plantas (Podostemaceae) na água agora rasa que corre sobre as rochas da corredeira; b) um peixe (aparentemente uma piaba, Characidae) é apanhado com o bico pela ave à direita; outro peixe pode ser notado saltando fora d'água em primeiro plano próximo ao cento da imagem; e c) a ave se desloca para um ponto mais alto para se alimentar do peixe, seguro entre as garras. A ave à esquerda na Figura $1 \mathrm{~b}$ também segura um peixe no bico. 
one extending into the water. Shallow water was channelled along this cleft, flowing rapidly but with much less speed and force than those of the current on the main channel, the current flow along the cleft likely being buffered by the vegetation. Additionally, a layer of water flowed among the podostemaceous plants.

The caracaras walked slowly in a small area along the channelled water, frequently stopping and peering intently into it and on the clumps of vegetation they walked on (Figure 1a). One of the birds was watched carefully during an observation session of 20 minutes and recorded to catch six small silvery fish that were moving upstream among the vegetation. As seen through the binoculars and on the photographs the fish probably were tetras (Characidae) about $5-7 \mathrm{~cm}$ long. Similar fish were occasionally seen jumping out of the water while trying to move upstream (Figure 1b).

Fish were caught by the bird either with the bill $(\mathrm{N}=4)$ or talons $(\mathrm{N}=2)$ with apparently little effort, as if the bird were picking a stationary or slow-moving item. After a successful catch, the bird walked to a spot a little further up from the water edge, held the fish with its talons and ate it (Figure 1c). The two other birds mostly kept a little downstream, and one of them sometimes walked to the fishing spot of the first bird and also caught a fish (Figure 1b). One of the birds keeping closer to the stretch with water plants aggressively displaced another individual fishing on a seemingly less favourable spot when the latter approached the fishing spot of the former. No food sharing was recorded. The remainder two caracaras either perched or flew around shrubs growing among the boulders, and did not interact directly with the fishing birds.

\section{Discussion}

Black Caracaras scavenging fish remains in riverside fishing camps, villages and towns - usually remarkably confident towards people - are a familiar sight throughout the Brazilian Amazon (see also Robinson 1994). Those birds would land near a morsel, pick it with the bill and fly to eat it elsewhere, or catch floating remains while on the wing in a way similar to the behaviour displayed by fishing Yellow-headed Caracaras Milvago chimachima (Vieillot) (Monteiro-Filho 1995, FO pers. obs.).

The fishing behaviour here reported for the Black Caracara at the Rio Roosevelt probably remained unrecorded to date more as a result of lack of observations rather than being a rare event. Fish upstream migration is a common phenomenon throughout the Amazon basin (and elsewhere in the Neotropics, see Lowe-McConnel 1975) and the rapids and waterfalls dotting the rivers draining the Brazilian Central Plateau into the Amazon lowlands provide ample opportunities for Black Caracaras to catch small fish rendered vulnerable by the exertion of negotiating the rapids, or trapped in shallow or narrow channels. Hunting live fish in migration bottlenecks is yet another foraging strategy among the varied behavioural portfolio displayed by the Caracarini (Sazima 2007).

\section{Acknowledgements}

Stephen Rumsey invited FO to this excursion to Rio Roosevelt. Gerard Bertrand, Edson Endrigo, Tasso Leventis and Marcelo Pádua for friendship during fieldwork. Sansão and Semi proved to be superb boat pilots while Barroso, Marivaldo and the Pousada staff assured a pleasant stay. IS thanks to the CNPq (Conselho Nacional de Desenvolvimento Científico e Tecnológico) for essential financial support. We thank two anonymous referees for their time and improvement of the text.

\section{References}

BATISTELLA, A.M. \& VOGT, R.C. 2008. Nesting ecology of Podocnemis erythrocephala (Testudines, Podocnemididae) of the Rio Negro, Amazonas, Brazil. Chelon. Conserv. Biol. 7(1): 12-20.

LOWE-McCONNELL, R.H. 1975. Fish communities in tropical freshwaters. Longman, London, $337 \mathrm{p}$.

MARTIN, P. \& BATESON, P. 1986. Measuring behaviour, an introductory guide. Cambridge University Press, Cambridge, $200 \mathrm{p}$.

MONTEIRO-FILHO, E.L.A. 1995. Fishing behavior of yellow-headed caracara, Milvago chimachima (Falconidae) in southeast Brazil. Ciênc. Cult. 47(1/2):86-87.

FERGUSON-LEES, J. \& CHRISTIE, D.A. 2001. Raptors of the world. Houghton Mifflin, Boston, $320 \mathrm{p}$.

GUIMARÃES Jr., J.J. \& GALETTI, M. 2004. Seed dispersal of Attalea phalerata (Palmae) by Crested caracaras (Caracara plancus) in the Pantanal and a review of frugivory by raptors. Rev. Bras. Ornitol. 12(2):133-135

OLMOS, F., PACHECO, J.F. \& SILVEIRA, L.F. 2006. Notas sobre aves de rapina (Cathartidae, Accipitridae e Falconidae) brasileiras. Rev. Bras. Ornitol. 14(3):427-430.

PERES, C.A. 1996. Ungulate ectoparasite removal by Black Caracaras and Pale-winged Trumpeter in Amazonian forests. Wilson Bull. 108(1):170-175.

ROBINSON, S.K. 1994. Habitat selection and foraging ecology of raptors in Amazonian Peru. Biotropica. 26(4):443-458.

SAZIMA, I. 2007. The jack-of-all-trades raptor: versatile foraging and wide trophic role of the Southern Caracara (Caracara plancus) in Brazil, with comments on feeding habits of the Caracarini. Rev. Bras. Ornitol. 15(4):592-597. 